Political Theory and Social Policy 


\section{Political Theory and Social Policy}

\section{Albert Weale}

Social Policy Research Unit

University of York

Macmillan Education 
(c) Albert Weale 1983

Softcover reprint of the hardcover 1st edition 1983 978-0-333-26416-4

All rights reserved. For information, write:

St. Martin's Press, Inc., 175 Fifth Avenue, New York, NY 10010 First published in the United States of America in 1983

ISBN 978-0-333-26417-1 ISBN 978-1-349-17144-6 (eBook)

DOI 10.1007/978-1-349-17144-6

\section{Library of Congress Cataloging in Publication Data}

Weale, Albert.

Political theory and social policy.

Bibliography: $p$.

Includes index.

1. Political science. 2. Social choice. 3. Social policy. I. Title.

JA74.W36 $1983 . \quad 361.6^{\prime} 14 \quad 83-42846$

ISBN 978-0-312-62553-5 


\section{Contents}

Preface vii

Acknowledgements $\quad$ x

1 Social Policy and the Scope of Political Theory 1

Social policy and economic policy 2

Normative political theory $\quad 7$

Components of a normative theory 11

$\begin{array}{ll}\text { Alternatives to utilitarianism } & 17\end{array}$

2 Welfare, Needs and the Theory of the Good 22

Subjective and objective theories of the good 23

Interpersonal comparisons of welfare $\quad 29$

Need and the concept of deprivation $\quad 35$

Internal and external preferences $\quad 38$

3 Autonomy, Freedom and Deprivation 4

The priority of autonomy $\quad 43$

Some qualifications $\quad 48$

Autonomy and freedom $\quad 49$

4 Freedom, Income and Education $\quad 59$

Principles of the social dividend 63

Autonomy and educational opportunity $\quad 72$

5 Contractarian Principles of Social Choice $\quad 80$

Equality, the Pareto principle and some assumptions $\quad 82$ 
vi Contents

The contractarian theory of social choice $\quad 85$

The hypothetical compensation test 90

Are contractarian principles acceptable? 93

6 Specific Egalitarianism 100

Needs and welfare $\quad 102$

Efficiency and specific egalitarianism $\quad 107$

Freedom of choice and specific egalitarianism 111

An alternative argument for specific egalitarianism $\quad 116$

7 Social Rights 122

The concept of a right 125

Human rights and social rights 127

Rights and benefits $\quad 135$

8 Procedures, Fairness and Efficiency 139

Conditions of procedural fairness 140

Procedural fairness and rationing devices 143

Efficiency and rationing devices $\quad 148$

Universality and selectivity $\quad 152$

9 Desert, Justice and Affirmative Action 157

The practice of merit $\quad 164$

Policies of affirmative action 168

Overriding merit? 172

10 Democracy and Participation $\quad 178$

The paradox of democracy 179

$\begin{array}{ll}\text { Types of democratic procedure } & 181\end{array}$

Integrating the models of democracy 188

Local autonomy and central relations $\quad 195$

Epilogue: Civility and Community 198

Notes and References 201

Index 221 


\section{Preface}

As individuals we stand in many and diverse relationships to one another. We bargain and we contract; we give or we receive orders; we are variously manager, supervisor, unionist, colleague, controller, worker, hireling, labourer, neighbour and citizen; in these roles we request, deny, cajole, entice, implore, excuse, explain or thank one another. To some other persons we stand in a special relationship like that of daughter, son, brother, sister, mother, father, friend or lover. Throughout these diverse relationships it is possible to ask one question: in what form of political community can we as individuals approach one another as free and autonomous persons?

I take this to be the central question with which the western tradition of political theory confronts us. Nor is the question merely theoretical. The political movements of liberalism and socialism have both been preoccupied with the problem of how human autonomy could develop in modern political and social conditions. For us (by which I mean those ordinary citizens of liberal democracies with only limited access to the corridors of power, who will, I suppose, constitute the bulk of those who read this book) these conditions are those of the welfare state. For us the question is: what does the welfare state contribute to the development of human autonomy?

This central problem of political evaluation has been answered in different ways. Some have seen the mechanisms of a redistributive tax-transfer scheme and the state supply of education and health services as steps down the road to serfdom. Others have seen the welfare state as providing a set of institutions through which individuals can realise the positive freedom that comes with identi- 
fying individual interest and the public interest. Yet others have seen the economic security provided by the welfare state as a necessary condition for the full enjoyment of the traditional civil and political liberties. And again others have seen the principle of satisfying needs, on which the welfare state supposedly rests, as prefiguring a form of social organisation in which persons are freed from the constraints of private property.

In what follows I have tried to offer an account of the relation between the welfare state and individual autonomy, and to show how the value of autonomy is connected with other values like justice, welfare and democracy. I begin by offering an account of normative political theory which I see as the enterprise of constructing a set of principles capable of justifying some forms of political arrangements relative to others. I then propose an account of what it means to say that a political arrangement is good for persons, and in the subsequent chapter give my understanding of the place of autonomy in the scheme of human goods. Chapter 4 explores the institutional question of what arrangements might secure individual autonomy; the claim I make is that a reform of income maintenance and educational programmes, with which we are already familiar in the welfare state, is sufficient to secure a minimally adequate level of autonomy. However, there are welfare considerations above the minimum, and Chapters 5 and 6 are taken up with the question of the principles upon which that welfare should be distributed, and a discussion of the fact that much current welfare state activity takes the form of in-kind programmes. The next chapter provides an account of rights that is intended to show how the concept of a right, so extensively used in popular discussions of politics and social policy, can be understood in a fashion consistent with the earlier theory I developed. Chapters 8 and 9 discuss specific problems in the functioning of resource-allocating mechanisms in the welfare state. The final chapter proposes a set of principles by which democratic responsibility for decision-making in the welfare state can be allocated.

Even if the argument were persuasive at each step it would not by itself settle the question of how we should evaluate any particular welfare state. A normative political theory provides a framework in which we can organise our thoughts; it does not provide a battery of instant diagnostic checks by application of which we can pass judgement on the health of the body politic and declare it fit or unfit. 
What, then, is the point of constructing such a theory? Why should we try to arrange our thoughts into general and coherent principles? One reason, of course, is simply to satisfy our intellectual curiosity and to exercise our minds on problems that have vexed those with vastly more capabilities than we have. Passion for the intellectual problems that politics raises is no more to be deprecated than any other sort of passion. There is, however, a more practical answer. We have to share a political community with those with whom we have our varied social relationships. Our relationship with most of our co-citizens is mediated through the state, with its power to allocate income, wealth, status, opportunities, burdens, benefits, rights, obligations, and even life and death. Unless we can explain to others how and why we think the state's powers can be used in some ways and not in others, we do not have a reciprocal political relationship with our co-citizens. We confront them merely with the brute force of power or the haphazard contingency of circumstance. To fit our particular opinions into a broader theory is to hold a political position, such that we can explain the grounds of our actions and judgement to those of our co-citizens who choose to question us. Perhaps one can lead a happy life if one is never confronted by the test of having to justify one's political stance and one's position in the world; but it is doubtful whether it could ever be a valuable life; or, at least, so the political theorist whom I'm imagining supposes. 


\section{Acknowledgements}

I have incurred many personal debts in writing this book which I should like to acknowledge. Its ground plan was laid during my period as visiting research fellow at the Institution for Social and Policy Studies, Yale University, in 1979. I should like to thank Charles E. Lindblom, who, as director, extended me the courtesy of this most remarkable academic establishment. I imagine that there are few places so stimulating to the political theorist. While at Yale I was privileged to participate in both the American Democratic Institutions seminar and the Legal Theory Workshop, the latter held at the Law School, and I learned much from those who took part in the discussions I shared in. I owe special thanks to Bruce Ackerman, James Fishkin, Theodore Marmor, Douglas Rae, Adina Schwartz and William White, each of whom has commented upon some particular aspect of the ideas this book contains, and from all of whom I have learned much about the relation of ideas to policy.

I continued to work on the book throughout 1980, enjoying in that year a visit to the University of Dar es Salaam, in Tanzania. Although my principal responsibilities involved teaching, I learned much about social policy in reflecting on the conditions of underdevelopment, and I should like to thank both Patrick Masanja and Severine Rugumamu, who acted as my guides to Tanzanian social and political life. I also thank the University of Dar es Salaam for providing hospitality which enabled me to think and write against the background of the ever-changing colours of the Indian Ocean. This is also the appropriate place to thank my colleagues at York, especially Peter Rutland in Politics and David Austen-Smith in Economics, for bearing my share of the load while I was away on those occasions. 
A central part of this book's argument draws upon earlier papers that I wrote with both Robert Sugden and Peter Lambert. I should like to thank them both for what I have learned from these collaborative efforts. Sally Baldwin, Tony Culyer, David Held and Raymond Plant have read and commented upon the manuscript, and I am grateful to them for their time and trouble. Ken Judge not only suggested that I write this book in the first place, but has commented in detail upon all its aspects and has unfailingly pointed to passages and arguments where I persist in error. Jonathan Bradshaw and Andrew Dunsire have given me much advice and support, and Hope Leresche extended me generous hospitality at various crucial stages. For secretarial services I thank Dorothy Daniel, Barbara Dodds, Julia Eastwood, Carole Hudson andSue Walters. I should also like to thank Alan King for compiling the index.

The dedication on the next page records how grateful I feel towards the person whose support, encouragement and advice made the writing of this book possible. 
To Jane 